\title{
On THE Optimal Size of PUblic SeCtor UNDER RENT-SEEKING COMPETITION FROM STATE COFFERS
}

\author{
HYUN PARK \\ APOSTOLIS PHILIPPOPOULOS \\ VANGELIS VASSILATOS \\ CESIFO WORKING PAPER No. 991 \\ CATEgory 5: Fiscal Policy, MaCROECONOMICS AND GROWTH \\ JULY 2003 \\ An electronic version of the paper may be downloaded \\ - from the SSRN website: \\ www.SSRN.com \\ - from the CESifo website: www.CESifo.de
}




\title{
On the Optimal Size of PUblic SeCtor UNDER RENT-SEEKING COMPETITION FROM STATE COFFERS
}

\begin{abstract}
This paper incorporates competition for fiscal transfers (or, equivalently, rent seeking from state coffers) into a standard general equilibrium model of economic growth and endogenously chosen fiscal policy. The government generates tax revenues, but then each selfinterested individual agent tries to extract, for his own personal benefit, a fraction of these revenues. Extracted tax revenues could alternatively be used to finance economy-wide infrastructure. We look at a Nash equilibrium in individual agents' behavior, and then investigate what the society should do to discourage rent-seeking competition. The focus is on the optimal size of public sector.
\end{abstract}

Keywords: social conflict, fiscal policy, economic growth.

JEL Code: D74, H3, O40.

\author{
Hyun Park \\ Kyung Hee University Seoul \\ \#1 Hoeki-dong, Dongdaemun-ku, \\ Seoul \\ Korea, 130-701
}

\author{
Apostolis Philippopoulos \\ Athens University of Economics and Business \\ 76 Patission Street \\ Athens 10434 \\ Greece \\ aphil@aueb.gr
}

\author{
Vangelis Vassilatos \\ Athens University of Economics and Business \\ 76 Patission Street \\ Athens 10434 \\ Greece
}

We thank Christos Kotsogiannis and Theodore Palivos for discussions and comments. We have also benefited from comments by George Economides, Miltos Makris, Jim Malley, Plutarchos Sakellaris and Stergios Skaperdas, as well as conference participants at the Summer School in Economic and Econometric Theory held in Crete 1-4 July 2002. All errors are ours. 


\section{INTRODUCTION}

Anecdotal and case study evidence across countries shows that politically influential interest groups attempt to appropriate national resources from the rest of society. This is particularly true in countries with "weak institutions". ${ }^{1}$ Concurrent theoretical work has shown that non-cooperative behavior can generate a destructive redistributive struggle over wealth that leads to lower economic growth [see, among others, Lane and Tornell (1996), Tornell and Lane (1999) and Mauro (2002)]. ${ }^{2}$

Motivated by the above, the present paper incorporates uncoordinated struggle for extra fiscal transfers into a model of growth and fiscal policy. We assume that the government collects tax revenues, but then each self-interested individual agent attempts to extract, for his own personal benefit, a fraction of these revenues. In other words, each individual rent-seeks from state coffers competing with other individuals. ${ }^{3}$ We then do two things. First, we provide a simple general equilibrium framework that may be useful to the study of various issues related to atomistic rentseeking behavior. Second, and more important, we endogenize economic policy and try to understand what the society should do to discourage such a behavior and reduce the associated social loss. Thus, analyzing socially optimal policy (and the associated size of public sector) under rent-seeking competition is the main difference from the literature.

Apparently, once one opens Pandora's box of rent seeking from state coffers, there is a whole range of possibilities depending on the organization and power of private agents versus the organization and power of government. ${ }^{4}$ Here, we will focus on a case in which a large number of private agents compete for extra fiscal transfers facing a weak state. For instance, Knack and Keefer

\footnotetext{
${ }^{1}$ See e.g. Lane and Tornell (1996) and Tornell and Lane (1999), and the empirical papers cited there. Weak institutions are associated with poor legal systems, insecure property and contract rights, social polarization, ethnic conflicts, low education rates, bureaucratic administrations, etc [see e.g. Knack and Keefer (1997), Rose-Ackerman (1999) and Easterly (2001)]. Then, in countries with weak institutions, special interests (e.g. industrial groups, public sector unions, bureaucrats, politicians, or even single firms) have the power to extract resources from the rest of society.

2 Tornell and Velasco (1992), Benhabib and Rustichini (1996) and Velasco (1998) also model non-cooperative behavior and competition for redistribution [see Drazen (2000, chapters 10 and 11) for a survey]. Transfers to special interests have always been an important issue [see e.g. Drazen (2000) and Persson and Tabellini (2000)].

3 The general theory is the theory of rent seeking, which refers to the socially costly pursuit of winning a contestable prize. In our paper, like in Mauro (2002), the prize is the (monopoly) rents that a government generates via coercive taxation. Then, individuals use their private resources to compete for these rents. See e.g. Drazen (2000, chapter 8) for a survey of rent seeking. Note that there is a strong similarity between rent seeking and common property models. That is, government assets can also be thought as a "common pool". Then, individuals, that have access to these assets, attempt to over-fish them for private benefit. See e.g. Drazen (2000, chapters 10 and 11) for a survey of appropriative behavior. Here, we will use the terms "rent seeking", "appropriation" and "extraction" interchangeably.

${ }^{4}$ For instance, Rose-Ackerman (1999, chapter 7) distinguishes four polar cases of corruption: first, the case in which powerful corrupt private agents facing a weak state can extract high private benefits without paying high bribes; second, the opposite extreme case in which a powerful head of government organizes the political system to maximize its rent-extraction possibilities facing a large number of weak private agents; third, a bilateral monopoly case in which powerful private interests face a corrupt ruler; fourth, a case of competitive corruption in which a large number of private agents deal with a large number of corrupt low-level government officials.
} 
(1997, p. 1256) assess the strength of institutions from responses to questions about "claiming government benefits which you are not entitled to" or "cheating on taxes if you have the chance". This is the idea in our model. In turn, given the possibility of rent seeking by self-interested individuals, we ask, "What is the expenditure-tax policy mix that maximizes the economy's growth rate?". That is, we assume that policy decisions are in the hands of a well-meaning government. This is because we want to understand what is optimal from the society's point of view, rather than to study "equilibrium" policy. Nevertheless, our normative results and insights carry over to more general environments in which government officials also rent seek. ${ }^{5}$

To make our results clear, we choose as a benchmark a widely used and simple model. In particular, we choose Barro's (1990) model of economic growth and endogenously chosen fiscal policy, in which government expenditures enhance the productivity of private firms. ${ }^{6}$ To this model, we add appropriative or rent-seeking competition for a fraction of collected tax revenues on the part of private agents. We look at a Nash equilibrium in private agents' behavior. This means that, in comparison with Barro's model, when the government chooses tax policy to maximize the economy's growth rate, it also tries to correct the social inefficiencies caused by rent-seeking competition. We then study the properties of optimal policy and its role in growth.

There are three main results: First, the possibility of extraction reduces economy-wide growth both directly (it reduces resources available for social infrastructure) and indirectly (it distorts the incentives of self-interested individuals by pushing them to appropriative activities). This is as in the literature. Second, for any feasible economic policy, a higher tax rate leads ceteris paribus to a lower fraction of effort allocated to work relative to appropriative activities. This is because individuals do not internalize the adverse effect of their appropriative activities on aggregate output. Hence, whenever the tax rate increases, they get the impression that the contestable prize (here, government tax revenue) also increases, and so attempt to extract a greater share of it by becoming more aggressive (see also Mauro (2002)). This is bad for growth. Third, when economic policy is endogenously chosen, and since a seemingly larger public sector triggers a more aggressive behavior on the part of self-interested individuals, the government finds it optimal to impose a relatively low tax rate (specifically, a tax rate lower than the one in Barro (1990)) so as to correct individuals' disincentives and push them to more socially efficient activities. By doing so, the government reduces (although it cannot eliminate) the deadweight loss arising from extraction.

\footnotetext{
${ }^{5}$ Laffont and Tirole (1998), Acemoglu and Verdier (2000) and Sarte (2000) also assume a benevolent central government in problems with private interest groups and corrupt low-level bureaucrats. As Laffont and Tirole (1998, $\mathrm{p}$. 479) point out this "is a first step toward a more general theory of regulatory politics" and "can be straightforwardly applied to cases in which the central government (Congress) does not maximize social welfare but tries to control the regulatory outcome". More discussion of this assumption is later.
} 
Therefore, the new result is that extraction should be associated with lower, rather than higher, tax rates. Even if tax revenues are earmarked for public investment, the size of public sector (measured by the government expenditure-to-output ratio) should be getting smaller and smaller as the possibility of extraction from state coffers increases. This normative result extends the positive results of Tornell and Lane (1999) and Mauro (2002). Note that adding more types of rent-seeking agents would not change our main point. By contrast, it would further call for lower tax rates and smaller public sectors. In other words, to the extent that agents (e.g. private agents, low-level government bureaucrats, top-level government officials, politicians, etc) are self-interested and so attempt to extract from the pool of tax revenues, the socially optimal tax rate, and the associated size of public sector, are relatively low.

The rest of the paper is as follows: Section II describes the model. Section III solves for a decentralized competitive equilibrium. Section IV solves for optimally chosen policy and a general equilibrium. Section V concludes.

\section{INFORMAL DESCRIPTION OF THE MODEL}

The key features of the model are as follows: (i) We build on Barro's (1990) model. Here, we also assume that individuals can extract from total tax revenues to increase their own personal wealth. In doing so, they compete with other individuals. This appropriative, or rent-seeking, competition is given by a Nash game among individuals. (ii) Appropriation comes at a private cost. $^{7}$ Specifically, it requires labor effort. ${ }^{8}$ Thus, each individual chooses optimally (in addition to consumption and saving) the allocation of its labor effort to work and appropriative activities. (iii) The amount of public sector income appropriated by each individual is proportional to the effort he, or she, allocates to the appropriative competition relative to the total effort allocated to appropriative competition by all individuals. (iv) This appropriative activity depletes the flow of social resources used as government production services. (v) A government (or perhaps the society) chooses economic policy to maximize the economy's growth rate. (vi) The sequence of events is as follows: Economic policy is chosen first, and in turn each private agent makes his allocation choices noncooperatively and simultaneously. This means that the government acts as a Stackelberg leader visà-vis decentralized private agents. The general equilibrium will be a subgame-perfect Nash

\footnotetext{
${ }^{6}$ Del Monte and Papagni (2001), Sarte (2001) and Mauro (2002) also use Barro's model to study rent seeking.

${ }^{7}$ Extracting transfers and favors from the government, cheating on taxes, bribing, lobbying, etc, are costly activities. In general, rent seeking (i.e. winning a contestable prize) requires the expenditure of private resources (time and effort).

${ }^{8}$ We could assume that extraction also requires private capital. This is not important.
} 
equilibrium in private decisions and the chosen policy. (vii) We assume infinite-time horizons, continuous time, certainty and commitment technology on the part of government. ${ }^{9}$

\section{DECENTRALIZED COMPETITIVE EQUILIBRIUM}

We will work with backward induction. Thus, this section solves for a decentralized competitive equilibrium for any feasible economic policy. Economic policy will be chosen in the next section.

\section{Firms' behavior}

Firms are indexed by $i \in I$ and are modeled as in Barro (1990). ${ }^{10}$ Each individual firm $i$ maximizes profits, $\pi^{i}$ :

$\pi^{i}=(1-\tau) y^{i}-r k^{i}-w l^{i}$

where $0<\tau<1$ is the output tax rate; ${ }^{11} y^{i}$ is output produced by firm $i ; k^{i}$ and $l^{i}$ are capital and labor used by firm $i$; and $r$ and $w$ are the interest rate and wage rate.

At the firm's level, the production function is:

$y^{i}=A G^{1-\alpha}\left(k^{i}\right)^{\alpha}\left(l^{i}\right)^{1-\alpha}$

where $G$ is public production services, $A>0$ and $0<\alpha<1$.

Each firm $i$ acts competitively by taking market prices $(r, w)$ and economic policy $(\tau, G)$ as given. When firm $i$ chooses $k^{i}$ and $l^{i}$, the first-order conditions are:

\footnotetext{
${ }^{9}$ The models closest to ours are those by Lane and Tornell (1996), Tornell and Lane (1999) and Mauro (2002). As said above, the key difference of our analysis is that here we endogenize economic policy. Then, the government has a nontrivial role to play: to internalize production externalities and individuals' atomistic incentives. There are also modeling differences (although this is less important). For instance, our model differs from that by Lane and Tornell (1996) and Tornell and Lane (1999) because in their work factor returns are exogenous and the common pool is the economy's capital stock rather than government tax revenue. Also, they focus on different issues. They show that an increase in the raw rate of return can reduce economic growth, because an increase in the raw rate of return leads self-interested groups to attempt to extract a greater share of national wealth. Demand for transfers is then reflected in higher tax rates (especially, in the formal sector) that reduce economy-wide growth. Mauro's (2002) model is similar to ours. For instance, like in our paper, the common pool is government tax revenue so that redistribution takes explicitly via government policy. On the other hand, he models rent seeking in a different way so as to focus on the role of strategic complementarities in generating multiple equilibria. Here, we use the rent seeking technology used by the literature on natural resources (see equation (5) below).

${ }^{10}$ We could assume that firms, like households, also extract public revenues; this is not important.
} 
$r=(1-\tau) \alpha \frac{y^{i}}{k^{i}}$

$w=(1-\tau)(1-\alpha) \frac{y^{i}}{l^{i}}$

\section{Households' behavior}

Households are also indexed by $i \in I$. Each individual household $i$ maximizes intertemporal utility:

$$
\int_{0}^{\infty} \log \left(c^{i}\right) e^{-\rho t}
$$

where $c$ is private consumption and $\rho>0$ is the discount factor.

The flow budget constraint of household $i$ is:

$$
\dot{k^{i}}+c^{i}=r k^{i}+\eta^{i} h^{i} w+\frac{\left(1-\eta^{i}\right) h^{i}}{\sum_{i=1}^{I}\left(1-\eta^{i}\right) h^{i}} \delta T
$$

where $0<\eta^{i} \leq 1$ and $0 \leq\left(1-\eta^{i}\right)<1$ are respectively the fractions of effort, $h^{i}$, that $i$ allocates to work and appropriative competition; $T$ is total government income; and $0 \leq \delta<1$ is the degree of economy-wide extraction (see below). That is, it is assumed that $\delta T$ can be stolen from the government, and then each $i$ attempts to extract a fraction of $\delta T$, where this fraction depends on the amount of effort that agent $i$ allocates to the appropriative competition relative to all agents. In other words, we borrow the extraction technology used extensively by the literature on natural resources; see e.g. Dasgupta and Heal (1979). Grossman (2000) also uses this technology in a property rights model. Note that a positive $\delta$ presupposes weak institutions.

Each household $i$ acts competitively by taking market prices $(r, w)$, economic policy $(T)$ and aggregate activity $\left(\delta, \sum_{i=1}^{I}\left(1-\eta^{i}\right) h^{i}\right)$ as given. ${ }^{12}$ Household $i$ chooses the paths of $c^{i}, k^{i}, \eta^{i}, h^{i}$.

\footnotetext{
${ }^{11}$ Since the model is $A K$ at social level (see below), the type of distortionary taxation assumed is not important.

${ }^{12}$ Each $i$ takes the degree of economy-wide extraction, $\delta$, as given. In equilibrium, $\delta$ will be endogenous and a function of the total rent-seeking activity in the economy (see ( $8 \mathrm{a})$ below). This is standard modeling. Note that we
} 
Without loss of generality, we assume $h^{i} \equiv 1$, i.e. total effort is equal to one in each time period. ${ }^{13}$ The first-order conditions for consumption, saving and extraction, $c^{i}, k^{i}, \eta^{i}$, imply:

$$
\begin{aligned}
& \dot{c}^{i}=c^{i}(r-\rho) \\
& w=\frac{\delta T}{\sum_{i=1}^{I}\left(1-\eta^{i}\right)}
\end{aligned}
$$

where (6a) is a standard Euler equation and (6b) implies that net returns from work and appropriative competition should be equal for the agent to be in equilibrium.

\section{Government budget constraint}

Assuming a balanced budget at each instant, the government's budget constraint is:

$G+\delta T=T$

where $T=\tau \sum_{i=1}^{I} y^{i}$ is total tax revenues. In other words, total tax revenues, $T$, finance public services, $G$, and total transfers, $\delta T$. Equivalently, only a part $0<(1-\delta) \leq 1$ of public sector income is used for public services because rent-seeking individuals capture the rest. ${ }^{14}$

\section{Decentralized competitive equilibrium}

We now solve for a Decentralized Competitive Equilibrium (DCE). This is defined to be a Nash equilibrium in individuals' decisions in which: (i) each individual firm maximizes its own profits; (ii) each individual household maximizes its own utility; (iii) all constraints are satisfied and all markets clear. ${ }^{15}$ A DCE holds for any feasible economic policy, where here policy is summarized by the tax rate, $0<\tau<1$. Obviously, a DCE is inefficient because private agents have ignored

could assume that each $i$ internalizes the effects of his/her own actions on aggregate outcomes. This is not important. What is important is that each $i$ takes the actions of other individuals $j \neq i$ as given.

${ }^{13}$ This justifies why labor effort was not included in the utility function (4) above.

${ }^{14}$ Our modeling in (5) and (7) is consistent with evidence. As e.g. The Economist, October 26th, 2002, p. 42, reports in an article about corruption: "Nothing shocks Angolans. It's normal, said one, referring to the disappearance of $\$ 4.3$ billion from state coffers in the past five years". For another motivation of (5) and (7), see the real-world examples provided by Mauro (2002, p. 7).

${ }^{15}$ Market clearing in the labor markets requires $L=\eta h$, where $h \equiv 1$. 
externalities. We will focus on a symmetric DCE, i.e. in equilibrium all firms and households are alike. ${ }^{16}$ Thus, from now on, the superscript $i$ will be omitted. Also, for notational simplicity, we set $I=1$, i.e. there is one firm and one household.

To close the model, we have to specify the degree of economy-wide extraction $(\delta)$. We assume that in equilibrium:

$$
\delta \equiv f\left(\sum_{i=1}^{I}\left(1-\eta^{i}\right) h^{i}\right)=f(1-\eta)
$$

where $f^{\prime}()>0,. f^{\prime \prime}(.) \leq 0 .{ }^{17}$ That is, in equilibrium, $\delta$ is a positive function of the total time spent in extraction activities. ${ }^{18}$ Specifically, to keep in line with the linear $A K$ structure of the model, we assume - without loss of generality - a linear function for $\delta:{ }^{19}$

$$
\delta \equiv \delta_{0}+\delta_{1}(1-\eta)
$$

where the constant term $\delta_{0} \geq 0$ reflects the idea that, in countries with weak institutions, there is a possibility of extra transfers independently of the effort each individual allocates to rent seeking, and the technology parameter $\delta_{1} \geq 0$ translates rent-seeking effort into extraction from state coffers. Notice that it must always be $0 \leq \delta<1$.

We can now solve for a DCE. It is easy to show that equations (1)-(8) give:

$$
\begin{aligned}
& \dot{c}=c\left((1-\tau) \alpha A^{\frac{1}{\alpha}}\left[\left(1-\left[\delta_{0}+\delta_{1}(1-\eta)\right]\right) \tau \eta\right]^{\frac{1-\alpha}{\alpha}}-\rho\right) \\
& \dot{k}=\left[1-\tau\left(1-\left[\delta_{0}+\delta_{1}(1-\eta)\right]\right)\right] A^{\frac{1}{\alpha}}\left[\left(1-\left[\delta_{0}+\delta_{1}(1-\eta)\right]\right) \tau \eta\right]^{\frac{1-\alpha}{\alpha}} k-c \\
& \eta=\frac{(1-\alpha)(1-\tau)}{(1-\alpha)(1-\tau)+\left[\delta_{0}+\delta_{1}(1-\eta)\right] \tau}
\end{aligned}
$$

\footnotetext{
${ }^{16}$ Solving for symmetric equilibria is not restrictive for what we do here. That is, we can still capture effects on incentives and therefore show how non-cooperative (Nash) and cooperative equilibria differ (see e.g. Cooper and John (1988) for the properties of symmetric Nash and cooperative equilibria). A simple way to get a cooperative equilibrium is to assume ex ante symmetricity in the optimization problem (4)-(5) above. Then, it is optimal to set $\eta$ at its highest possible value, i.e. $\eta=1$. Thus, when economic agents do not compete for extra transfers, all effort goes to work.

${ }^{17}$ Recall that, in equilibrium, all agents are alike and there is one agent. Also, $h \equiv 1$.

${ }^{18}$ See also e.g. Zak and Knack (2001) and Mauro (2002).

${ }^{19}$ We have experimented with richer functional forms and the main results do not change.
} 
where (9a)-(9c) give the paths of $(c, k, \eta)$. This is for any feasible economic policy, $0<\tau<1$.

Therefore, we have:

Proposition 1: Given economic policy $0<\tau<1$, there is a unique Decentralized Competitive Equilibrium (DCE), which is summarized by equations $(9 a)-(9 c)$. In this equilibrium, there is rentseeking behavior, $0<\eta<1$.

\section{Proof: See Appendix A.}

To understand the logic of the model, we present comparative static results in a DCE. Since analytical results are not possible in general, ${ }^{20}$ we resort to numerical simulations. Table 1 below reports the effects of a changing tax rate, $\tau$, on the fraction of effort that each individual allocates to work relative to rent seeking, $\eta$, the degree of economy-wide extraction, $\delta$, the economy's consumption growth rate, $\gamma \equiv \frac{\dot{c}}{c}$, and the consumption-to-capital ratio, $c / k$. The results show that a higher $\tau$ leads monotonically to lower $\eta$ and higher $\delta$, while there is [as in Barro (1990)] a Laffer-curve type effect from $\tau$ to $\gamma$ and $c / k{ }^{21}$

\section{Table 1 here}

The main result is $\frac{\partial \eta}{\partial \tau}<0$. That is, other things equal, a higher tax rate leads to a lower fraction of labor effort allocated to work relative to appropriative activities. This happens because private agents do not internalize the adverse effect of their appropriative activities on aggregate output, or equivalently the tax base, $y$. Hence, whenever the tax rate, $\tau$, increases, they get the impression that the contestable prize, $\delta T=\delta \tau y$, also increases and so attempt to extract a greater share of it by demanding more transfers. This aggressive behavior is at the cost of time allocated to work, $\eta$ [see also Mauro (2002)]. In turn, as (9a) implies, this is at the society's expense (a lower $\eta$ leads to lower growth in a DCE).

\footnotetext{
${ }^{20}$ Equation (9c) implies $\frac{\partial \eta}{\partial \tau}=\frac{-[(1-\alpha)(1-\eta)+f(1-\eta) \eta]}{\left[(1-\alpha)(1-\tau)+\tau f(1-\eta)-f^{\prime}(1-\eta) \eta\right]}$, whose sign is ambiguous. Only if we set $\delta_{1}=0$ so that $f^{\prime}()=$.0 in $(8 \mathrm{a})-(8 \mathrm{~b})$, this sign is unambiguously negative.

${ }^{21}$ The growth rate, $\gamma$, can easily become positive if we set the productivity parameter, $A$, higher than one. Since this is not important, we just set $A=1$ in all numerical examples.
} 
Table 2 below reports the effects of a changing $\delta_{0}$ (see (8b) above). A higher $\delta_{0}$ leads monotonically to lower $\eta$, higher $\delta$, and lower $\gamma$ and $c / k$. Table 3 reports similar effects of a changing $\delta_{1}$ (again see ( $8 \mathrm{~b}$ ) above). In other words, higher $\delta_{0}$ and $\delta_{1}$ (and hence higher $\delta$ ) reduce economy-wide economic growth both directly (see (9a)) and indirectly (via a decrease in $\eta$; see (9c)). The direct effect arises simply because there are less social resources available to finance public infrastructure. The indirect effect arises because the possibility of extraction distorts individuals' incentives and pushes them to appropriative activities, which are socially harmful. Therefore, we get the standard result of the literature; namely, rent seeking is detrimental to growth.

Tables 2 and 3 here

\section{ENDOGENOUSLY CHOSEN POLICY AND GENERAL EQUILIBRIUM}

We now endogenize the choice of economic policy, as summarized by the tax rate, $0<\tau<1$. Following Barro (1990) and most of the endogenous growth literature, we assume that $\tau$ is chosen by a well-meaning government, whose objective is to maximize the economy's consumption growth rate. In doing so, the government takes into account the DCE derived above, and thus solves a second-best policy problem.

Note that the objective of a well-meaning government could alternatively be to maximize households' lifetime utility as in the standard optimal tax Ramsey problem. Whether the government maximizes economy-wide growth, or households' utility, does not matter for our qualitative results. What does matter is the assumption that the central authority does not rent seek itself. As said in the Introduction above, we make this assumption because here we want to address the question of the optimal size of public sector from the society's viewpoint. That is, as Laffont and Tirole (1998, p. 475) point out, we follow the "public interest" theory of policy emphasizing the government's role in correcting imperfections (here, in the form of production externalities and appropriative competition for fiscal transfers).

\section{Socially optimal policy}

The planner chooses the tax rate, $\tau$, to maximize the consumption growth rate in (9a). The solution to this optimization problem gives:

Proposition 2: There is an optimal tax rate, $\tau^{*}$, that maximizes the economy-wide consumption growth rate. This tax rate is a solution to: 
$0<\tau^{*}=\frac{(1-\alpha)(1+\varepsilon)}{(1-\alpha)(1+\varepsilon)+\alpha}<1-\alpha<1$

where $\varepsilon \equiv \frac{\partial \eta}{\partial \tau} \frac{\tau}{\eta}\left(1+\frac{f^{\prime}(1-\eta) \eta}{(1-f(1-\eta))}\right)$ and $\frac{\partial \eta}{\partial \tau}=\frac{-[(1-\alpha)(1-\eta)+f(1-\eta) \eta]}{\left[(1-\alpha)(1-\tau)+\tau f(1-\eta)-\tau f^{\prime}(1-\eta) \eta\right]}$.

Proof: See Appendix B.

A general equilibrium is summarized by (9a)-(9c) and (10). We can first solve (9c) and (10) simultaneously for $\eta$ and $\tau .{ }^{22}$ In turn, (9a) gives the so-called balanced growth path, $\gamma \equiv \frac{\dot{c}}{c}=\frac{\dot{k}}{k}$, i.e. the common constant rate at which $c$ and $k$ can grow positively. Finally, (9b) can give the consumption-to-capital ratio, $c / k .^{23}$

Proposition 2 shows that $\tau^{*}$ lies in the region $0<\tau<1-\alpha$. That is, the chosen tax rate (and the associated size of public sector $)^{24}$ are smaller than the productivity of government expenditures, $(1-\alpha)$, which is Barro's popular result. Intuitively, since a higher tax rate gives a wrong signal to individuals that the pie (total tax revenues) gets larger, the government finds it optimal to impose a relatively low tax rate to correct individuals' disincentives. By doing so, the government aims to discourage self-interested individuals from going for extraction and thereby push them to use their private resources more efficiently.

Tables 4 and 5 below report numerical results in general equilibrium. ${ }^{25}$ Table 4 shows the effects of the autonomous part of extraction, $\delta_{0}$, on all endogenous variables including the optimally chosen tax rate, $\tau^{*}$. As $\delta_{0}$ increases, the tax rate, $\tau^{*}$, falls monotonically, while the total degree of extraction, $\delta$, increases monotonically. The idea is that the government chooses a smaller and smaller tax rate in order to counterbalance the adverse effects of a rising $\delta_{0}$. Nevertheless, the policy control is less than perfect because, although $\tau^{*}$ falls to correct individuals' disincentives, the direct effect dominates so that the overall degree of extraction, $\delta$, increases (see (8b) above).

\footnotetext{
${ }^{22}$ In our setup, it is optimal to keep tax policy, $\tau$, and the allocation of work effort, $\eta$, flat over time. In other words, $\tau$ and $\eta$ are not state-contingent. See Drazen (2000, chapter 11) for a survey of state-independent and state-dependent behavior in models with extraction.

${ }^{23}$ When $c$ and $k$ grow at the same rate along the long-run balanced growth path, equations (9a)-(9b) give $\frac{c}{k}=\rho+[(1-\alpha)(1-\tau)+\delta \tau] A^{\frac{1}{\alpha}}((1-\delta) \eta \tau)^{\frac{1-\alpha}{\alpha}}>0$. Then, it is easy to see that the eigenvalues are unstable so that, with forward-looking variables, the economy jumps to its long-run equilibrium and there are no transitional dynamics as in the basic $A K$ model. See Park and Philippopoulos (2002) for details.

${ }^{24}$ As (7) shows, the tax rate equals the government expenditure-to-output ratio.

${ }^{25}$ Notice that $\tau^{*}$ is always less than $(1-\alpha)=0.6$, which is Barro's (1990) tax rate. This is as in Proposition 2.
} 
As a result, $\gamma$ and $c / k$ fall monotonically. This less-than-perfect control is also shown by the fact that, although policy is optimally chosen, the growth rate $(\gamma)$ is always lower than in the benchmark case in which $\delta=0$ (in this Barro-case, as the first row of Table 4 reports, $\tau=0.6, \gamma=0.0544$ and $c / k=0.0632$ ). Finally, notice in Table 4 that the effect of $\delta_{0}$ upon $\eta$ is U-shaped. Intuitively, as the opportunities of extraction increase, the fraction of effort that each individual allocates to work relative to rent seeking falls initially, but then it starts increasing as the size of the pie (government tax revenue) gets smaller and smaller. It is worth pointing out that this general equilibrium effect of $\delta_{0}$ upon $\eta$ differs from the one in a DCE analyzed in the previous section. Specifically, in Table 2 above, a higher $\delta_{0}$ led monotonically to lower $\eta$; this was for given policy. Now, where policy is endogenously chosen, the government can stop the fall in $\eta$ by choosing a small enough public sector (and so mitigate the adverse effects of a rising $\delta_{0}$ ). Table 5 reports that the effects of $\delta_{1}$ are qualitatively similar to those of $\delta_{0}$.

Tables 4 and 5 here

Therefore, the main results are: (a) from a social welfare point of view, the intensity of extraction and the size of the public sector should move in opposite directions; ${ }^{26}$ (b) the government cannot fully correct the distortion arising from the possibility of extraction, simply because it does not have enough policy instruments at its disposal.

Special cases $\left(\delta_{0}=0\right.$ or $\left.\delta_{1}=0\right)$

It is interesting to discuss two special cases. First, when $\delta_{0}=0$ in (8b) above. That is, the degree of economy-wide extraction is determined entirely by the total time spent in extraction activities. This is studied in Appendix C. In this case, there can be two DCE: a good equilibrium without rent seeking, $\eta_{1}=1$; and a bad equilibrium with rent seeking, $\eta_{2}<1$, if the tax rate (or equivalently the size of public sector) is large enough. Intuitively, in the absence of an institutionally given extraction $\left(\delta_{0}\right)$ that unambiguously makes rent seeking the dominant behavior, there can be an expectations coordination problem. Atomistic individuals can coordinate their actions to an outcome without rent seeking, but it is equally possible that rent seeking becomes their self-

\footnotetext{
${ }^{26}$ When the government also rent seeks (i.e. it is not benevolent), $\delta$ and $\tau$ might move in the same direction, especially when there are connections between policymakers and private interest groups sharing the extra rents. In our model, this can be shown by assuming that the government chooses tax policy so as to maximize a weighted sum of the economy's growth rate and extracted resources enjoyed by private interest groups.
} 
fulfilling belief. ${ }^{27}$ In turn, when the government chooses policy, it sets $\tau^{*}=1-\alpha$ so that $\eta=1$. In other words, the benevolent government uses its policy instrument to select the good equilibrium and lead the economy to Barro's second-best solution.

Second, when $\delta_{1}=0$ in ( $\left.8 \mathrm{~b}\right)$ above. That is, now the degree of economy-wide extraction is institutionally given, $\delta=\delta_{0}>0$. In this case, all results of the general case hold. In addition, as Appendix D shows, we can get an analytical solution and there is a unique tax rate in Proposition 2.

\section{CONCLUDING REMARKS AND EXTENSIONS}

This paper considered an economy where self-interested individuals competed for national wealth. Specifically, we extended Barro's (1990) model. In this model, on the one hand, government services enhance the productivity of private firms; on the other hand, the provision of government services requires distorting taxes. This produces a tradeoff in fiscal policy that can determine the optimal tax rate and the associated optimal size of public sector. Here, to this tradeoff, we added rent-seeking competition for a fraction of collected tax revenues.

Since our results have been written in the Introduction, here we only discuss two extensions. First, we focused on rent seeking by private actors ignoring rent seeking by government officials. It is known that low-level government bureaucrats and top-level government officials also rent seek at the citizens' expense. As argued above, to the extent that the key human motivator is the same (i.e. self-interest), so that people get more aggressive as the contestable prize increases, our main normative result is not expected to change. Nevertheless, it would still be interesting to model the interaction between corrupt private actors and corrupt government officials in a general equilibrium model of growth and endogenously chosen policy. Second, here we took weak institutions as given, i.e. we assumed that extraction is possible, and then studied its implications. That is, we focused on the demand side of rent seeking. While this is as in most of the literature, an interesting extension could be to explain how the possibility of extraction arises in the first place (i.e. why $\delta$ is positive in equation (5)). In other words, as Laffont (2000) points out, it is also important to open the black box of the supply side of rent seeking. We leave these extensions for future research.

\footnotetext{
${ }^{27}$ Mauro (2002) also gets multiple DCE. However, this is due to strategic complementarities in his paper.
} 


\section{APPENDIX}

\section{A. Proof of Proposition 1}

Eq. (9c) gives a quadratic equation in $\eta, \eta^{2}-\left(\frac{(1-\alpha)(1-\tau)+\left(\delta_{0}+\delta_{1}\right) \tau}{\delta_{1} \tau}\right) \eta+\frac{(1-\alpha)(1-\tau)}{\delta_{1} \tau}=0$. Say that there are two real roots, denoted as $\eta_{1}$ and $\eta_{2}$. Since $0<\alpha<1$ and $0<\tau<1$, both roots are positive. Also, $\left(\eta_{1}-1\right)\left(\eta_{2}-1\right)=\frac{-\delta_{0}}{\delta_{1}}<0$. Hence, one root is higher than one, while the other root is positive but less than one. Only the latter is acceptable, so there is a unique solution $0<\eta<1$. In turn, (9a) and (9b) give a unique solution for the other endogenous variables (for details, see below Proposition 2 in the main text).

\section{B. Proof of Proposition 2}

Maximizing $\frac{\dot{c}}{c}$ in $(9 a)$ with respect to $\tau$ gives $(1-\alpha)(1-\tau)(1+\varepsilon)=\alpha \tau$, or $\tau^{*}=\frac{(1-\alpha)(1+\varepsilon)}{(1-\alpha)(1+\varepsilon)+\alpha}$, where $\varepsilon \equiv \frac{\partial \eta}{\partial \tau} \frac{\tau}{\eta}\left(1+\frac{f^{\prime}(1-\eta) \eta}{(1-f(1-\eta))}\right), \frac{\partial \eta}{\partial \tau}=\frac{-[(1-\alpha)(1-\eta)+f(1-\eta) \eta]}{\left[(1-\alpha)(1-\tau)+\tau f(1-\eta)-\tau f^{\prime}(1-\eta) \eta\right]}$ and the function $f($.$) is as in (8a). For this equation to hold, (1+\varepsilon)>0$ so that $0<\tau^{*}<1$. Also, if $\frac{\partial \eta}{\partial \tau}<0$ (which is what Table 1 shows) and hence $-1<\varepsilon<0$, we have $\tau^{*}<1-\alpha$. Notice that we cannot exclude the possibility of multiple solutions for $\tau^{*}$. See Park and Philippopoulos (2003) for a more general growth model that shows the possibility of multiple general equilibria (optimal tax Ramsey equilibria), even when there is a unique competitive equilibrium for given policy.

\section{The special case $\delta_{0}=0$}

Let us go back to Appendix A. Then, if $\delta_{0}=0,\left(\eta_{1}-1\right)\left(\eta_{2}-1\right)=0$. Hence, one root is equal to one; say $\eta_{1}=1$. But then $\eta_{2}=\frac{(1-\alpha)(1-\tau)}{\delta_{1} \tau}$, which is less than one if $\tau>\frac{(1-\alpha)}{\left(1-\alpha+\delta_{1}\right)}$. Therefore, it is possible to have two solutions in a DCE: one without rent seeking, $\eta_{1}=1$; and one with rent seeking, $\eta_{2}<1$, if the tax rate is high enough. Next, let us go back to Appendix B, which studies general equilibrium. Then, if $\delta_{0}=0$, it is easy to show that $\varepsilon=0$ so that $\tau^{*}=1-\alpha$ and $\eta=1$. 
D. The special case $\delta_{1}=0$

We again have $(1-\alpha)(1-\tau)(1+\varepsilon)=\alpha \tau$ as in Appendix $\mathrm{B}$ above, but now $\varepsilon \equiv \frac{\partial \eta}{\partial \tau} \frac{\tau}{\eta}=\frac{-\delta \tau}{(1-\tau)[(1-\alpha)(1-\tau)+\delta \tau]}<0 . \quad$ Thus, we get a quadratic equation in $\tau$, $(1-\alpha-\delta) \tau^{2}-(1-\alpha)(2-\alpha) \tau+(1-\alpha)^{2}=0$. Say that there are two real roots, $\tau_{1}$ and $\tau_{2}$. It is convenient to distinguish two cases: (a) when $(1-\alpha-\delta)<0$ and (b) when $(1-\alpha-\delta)>0$. In either case, if we check the sign of $\left(\tau_{1}-1\right)\left(\tau_{2}-1\right)$, it follows that there is only one solution in the right region, namely between 0 and 1 . In particular, in case (a), it must be $0<\tau_{1}<0$ and $\tau_{2}<0$; while, in case (b), it must be $0<\tau_{1}<0$ and $\tau_{2}>1$. Therefore, there is a unique solution, $0<\tau^{*}<1-\alpha$. 


\section{REFERENCES}

Acemoglu D. and T. Verdier (2000): The choice between market failures and corruption, American Economic Review, 90, 194-211.

Barro R. (1990): Government spending in a simple model of economic growth, Journal of Political Economy, 98, S103-S125.

Benhabib J. and A. Rustichini (1996): Social conflict and growth, Journal of Economic Growth, 1, 125-142.

Cooper R. and A. John (1988): Coordinating coordination failures in Keynesian models, Quarterly Journal of Economics, 103, 441-463.

Dasgupta P. and G. Heal (1979): Economic Theory and Exhaustible Resources. Cambridge University Press, Cambridge.

Del Monte A. and E. Papagni (2001): Public expenditure, corruption and economic growth: the case of Italy, European Journal of Political Economy, 17, 1-16.

Drazen A. (2000): Political Economy in Macroeconomics. Princeton University Press, Princeton, New Jersey.

Easterly W. (2001): The Elusive Quest for Growth. The MIT Press, Cambridge, Mass.

Grossman H. (2000): The creation of effective property rights, Working Paper, no. 00-15, Brown University, Providence.

Knack S. and P. Keefer (1977): Does social capital have an economic payoff? A cross-country investigation, Quarterly Journal of Economics, 112, 1251-1287.

Laffont J.-J. (2000): Incentives and Political Economy. Oxford University Press, Oxford.

Laffont J.-J. and J. Tirole (1998): A Theory of Incentives in Procurement and Regulation. The MIT Press, Cambridge, Mass.

Lane P. and A. Tornell (1996): Power, growth and the voracity effect, Journal of Economic Growth, 1, 213-241.

Mauro P. (2002): The persistence of corruption and slow economic growth, IMF Working Paper, 02/213, International Monetary Fund, Washington.

Park H. and A. Philippopoulos (2002): Dynamics of taxes, public services and endogenous growth, Macroeconomic Dynamics, 6, 187-201.

Park H. and A. Philippopoulos (2003): Indeterminacy and fiscal policies in a growing economy, forthcoming in Journal of Economic Dynamics and Control.

Persson T. and G. Tabellini (2000): Political Economics: Explaining Economic Policy. MIT Press, Cambridge, Mass. 
Rose-Ackerman S. (1999): Corruption and Government. Cambridge University Press, Cambridge.

Sarte P.D. (2000): Informality and rent-seeking bureaucracies in a model of long-run growth, Journal of Monetary Economics, 46, 173-197.

Sarte P.D. (2001): Rent-seeking bureaucracies and oversight in a simple growth model, Journal of Economic Dynamics and Control, 25, 1345-1365.

Tornell A. and P. Lane (1999): The voracity effect, American Economic Review, 89, 22-46.

Tornell A. and A. Velasco (1992): The tragedy of the commons and economic growth: why does capital flow from poor to rich countries? Journal of Political Economy, 100, 1208-1231.

Velasco A. (1998): A model of fiscal deficits and delayed fiscal reforms, in Fiscal Institutions and Fiscal Performance, edited by J. Poterba and J. Von Hagen. University of Chicago Press, Chicago.

Zak P. and S. Knack (2001): Trust and growth, Economic Journal, 111, 295-321. 


\section{TABLES}

Table 1: effects of $\tau$ in DCE

\begin{tabular}{||l||l|l|l|l||}
\hline \hline$\tau$ & $\eta$ & $\delta$ & $\gamma$ & $c / k$ \\
\hline \hline 0.10 & 0.9633 & 0.2071 & -0.0124 & 0.0310 \\
\hline 0.20 & 0.9173 & 0.2165 & -0.0026 & 0.0448 \\
\hline 0.30 & 0.8603 & 0.2276 & 0.0049 & 0.0550 \\
\hline 0.40 & 0.7880 & 0.2424 & 0.0080 & 0.0599 \\
\hline 0.50 & 0.6976 & 0.2602 & 0.0062 & 0.0593 \\
\hline 0.60 & 0.5877 & 0.2812 & 0.0004 & 0.0543 \\
\hline 0.70 & 0.4534 & 0.3093 & -0.0077 & 0.0458 \\
\hline
\end{tabular}

Note: $\alpha=0.4, \quad A=1, \quad \rho=0.04, \quad \delta_{0}=0.20, \quad \delta_{1}=0.20$.

Table 2: effects of $\delta_{0}$ in DCE

\begin{tabular}{||l||l|l|l|l||}
\hline$\delta_{0}$ & $\delta$ & $\eta$ & $\gamma$ & $c / k$ \\
\hline \hline 0 & 0 & 1 & 0.0260 & 0.0702 \\
\hline 0.10 & 0.1152 & 0.9242 & 0.0140 & 0.0625 \\
\hline 0.20 & 0.2276 & 0.8603 & 0.0049 & 0.0550 \\
\hline 0.30 & 0.3389 & 0.8054 & -0.0021 & 0.0479 \\
\hline 0.40 & 0.4485 & 0.7575 & -0.0076 & 0.0414 \\
\hline 0.50 & 0.5568 & 0.7156 & -0.0118 & 0.0355 \\
\hline 0.60 & 0.6643 & 0.6783 & -0.0150 & 0.0302 \\
\hline 0.70 & 0.7709 & 0.6451 & -0.0174 & 0.0258 \\
\hline 0.80 & 0.8767 & 0.6153 & -0.0190 & 0.0223 \\
\hline 0.90 & 0.9824 & 0.5879 & -0.0200 & 0.0201 \\
\hline \hline
\end{tabular}

Note: $\alpha=0.4, \quad A=1, \quad \rho=0.04, \quad \tau=0.30, \quad \delta_{1}=0.20$.

Table 3: effects of $\delta_{1}$ in DCE

\begin{tabular}{||l||l|l|l|l||}
\hline \hline$\delta_{1}$ & $\delta$ & $\eta$ & $\gamma$ & $c / k$ \\
\hline \hline 0 & 0.2000 & 0.8750 & 0.0069 & 0.0568 \\
\hline 0.10 & 0.2128 & 0.8683 & 0.0060 & 0.0560 \\
\hline 0.20 & 0.2276 & 0.8603 & 0.0049 & 0.0550 \\
\hline 0.30 & 0.2447 & 0.8513 & 0.0037 & 0.0539 \\
\hline 0.40 & 0.2633 & 0.8420 & 0.0025 & 0.0527 \\
\hline 0.50 & 0.2832 & 0.8331 & 0.0012 & 0.0514 \\
\hline 0.60 & 0.3081 & 0.8197 & -0.0003 & 0.0499 \\
\hline 0.70 & 0.3352 & 0.8068 & -0.0019 & 0.0482 \\
\hline 0.80 & 0.3655 & 0.7932 & -0.0036 & 0.0463 \\
\hline 0.90 & 0.3951 & 0.7822 & -0.0051 & 0.0445 \\
\hline 1.00 & 0.4334 & 0.7660 & -0.0069 & 0.0422 \\
\hline \hline
\end{tabular}

Note: $\alpha=0.4, \quad A=1, \quad \rho=0.04, \quad \tau=0.30, \quad \delta_{0}=0.20$. 
Table 4: effects of $\delta_{0}$ in general equilibrium

\begin{tabular}{||l||l|l|l|l|l||}
\hline$\delta_{0}$ & $\delta$ & $\eta$ & $\tau$ & $\gamma$ & $c / k$ \\
\hline \hline 0 & 0 & 1 & 0.6000 & 0.0544 & 0.0632 \\
\hline 0.10 & 0.1306 & 0.8441 & 0.4597 & 0.0223 & 0.0688 \\
\hline 0.20 & 0.2443 & 0.7778 & 0.4126 & 0.0081 & 0.0601 \\
\hline 0.30 & 0.3530 & 0.7348 & 0.3804 & -0.0009 & 0.0513 \\
\hline 0.40 & 0.4591 & 0.7044 & 0.3542 & -0.0072 & 0.0432 \\
\hline 0.50 & 0.5631 & 0.6837 & 0.3301 & -0.0117 & 0.0362 \\
\hline 0.60 & 0.6654 & 0.6725 & 0.3050 & -0.0150 & 0.0303 \\
\hline 0.70 & 0.7649 & 0.6747 & 0.2743 & -0.0174 & 0.0256 \\
\hline 0.80 & 0.8591 & 0.7040 & 0.2270 & -0.0190 & 0.0222 \\
\hline 0.90 & 0.9393 & 0.7954 & 0.1410 & -0.0198 & 0.0204 \\
\hline
\end{tabular}

Note: $\alpha=0.4, \quad A=1, \quad \rho=0.04, \quad \delta_{1}=0.20$.

Table 5: effects of $\delta_{1}$ in general equilibrium

\begin{tabular}{||l||l|l|l|l|l||}
\hline \hline$\delta_{1}$ & $\delta$ & $\eta$ & $\tau$ & $\gamma$ & $c / k$ \\
\hline \hline 0 & 0.1999 & 0.7754 & 0.4651 & 0.0132 & 0.0640 \\
\hline 0.05 & 0.2108 & 0.7754 & 0.4522 & 0.0119 & 0.0632 \\
\hline 0.10 & 0.2222 & 0.7754 & 0.4391 & 0.0106 & 0.0622 \\
\hline 0.15 & 0.2335 & 0.7762 & 0.4258 & 0.0093 & 0.0612 \\
\hline 0.20 & 0.2442 & 0.7779 & 0.4125 & 0.0081 & 0.0601 \\
\hline 0.25 & 0.2549 & 0.7798 & 0.3994 & 0.0069 & 0.0590 \\
\hline 0.30 & 0.2652 & 0.7821 & 0.3865 & 0.0057 & 0.0577 \\
\hline 0.35 & 0.2750 & 0.7853 & 0.3737 & 0.0046 & 0.0565 \\
\hline 0.40 & 0.2844 & 0.7887 & 0.3612 & 0.0035 & 0.0553 \\
\hline 0.45 & 0.2932 & 0.7924 & 0.3491 & 0.0025 & 0.0540 \\
\hline 0.50 & 0.3017 & 0.7962 & 0.3374 & 0.0015 & 0.0528 \\
\hline 0.55 & 0.3093 & 0.8008 & 0.3261 & 0.0006 & 0.0516 \\
\hline \hline
\end{tabular}

Note: $\alpha=0.4, \quad A=1, \quad \rho=0.04, \quad \delta_{0}=0.20$. 


\title{
CESifo Working Paper Series
}

\author{
(for full list see www.cesifo.de)
}

926 Rudi Dornbusch and Stanley Fischer, International Financial Crises, April 2003

927 David-Jan Jansen and Jakob de Haan, Statements of ECB Officials and their Effect on the Level and Volatility of the Euro-Dollar Exchange Rate, April 2003

928 Mario Jametti and Thomas von Ungern-Sternberg, Assessing the Efficiency of an Insurance Provider - A Measurement Error Approach, April 2003

929 Paolo M. Panteghini and Guttorm Schjelderup, Competing for Foreign Direct Investments: A Real Options Approach, April 2003

930 Ansgar Belke, Rainer Fehn, and Neil Foster, Does Venture Capital Investment Spur Employment Growth?, April 2003

931 Assar Lindbeck, Sten Nyberg, and Jörgen W. Weibull, Social Norms and Welfare State Dynamics, April 2003

932 Myrna Wooders and Ben Zissimos, Hotelling Tax Competition, April 2003

933 Torben M. Andersen, From Excess to Shortage - Recent Developments in the Danish Labour Market, April 2003

934 Paolo M. Panteghini and Carlo Scarpa, Irreversible Investments and Regulatory Risk, April 2003

935 Henrik Jacobsen Kleven and Claus Thustrup Kreiner, The Marginal Cost of Public Funds in OECD Countries. Hours of Work Versus Labor Force Participation, April 2003

936 Klaus Adam, George W. Evans, and Seppo Honkapohja, Are Stationary Hyperinflation Paths Learnable?, April 2003

937 Ulrich Hange, Education Policy and Mobility: Some Basic Results, May 2003

938 Sören Blomquist and Vidar Christiansen, Is there a Case for Public Provision of Private Goods if Preferences are Heterogeneous? An Example with Day Care, May 2003

939 Hendrik Jürges, Kerstin Schneider, and Felix Büchel, The Effect of Central Exit Examinations on Student Achievement: Quasi-experimental Evidence from TIMSS Germany, May 2003

940 Samuel Bentolila and Juan F. Jimeno, Spanish Unemployment: The End of the Wild Ride?, May 2003 
941 Thorsten Bayindir-Upmann and Anke Gerber, The Kalai-Smorodinsky Solution in Labor-Market Negotiations, May 2003

942 Ronnie Schöb, Workfare and Trade Unions: Labor Market Repercussions of Welfare Reform, May 2003

943 Marko Köthenbürger, Tax Competition in a Fiscal Union with Decentralized Leadership, May 2003

944 Albert Banal-Estañol, Inés Macho-Stadler, and Jo Seldeslachts, Mergers, Investment Decisions and Internal Organisation, May 2003

945 Kaniska Dam and David Pérez-Castrillo, The Principal-Agent Matching Market, May 2003

946 Ronnie Schöb, The Double Dividend Hypothesis of Environmental Taxes: A Survey, May 2003

947 Erkki Koskela and Mikko Puhakka, Stabilizing Competitive Cycles with Distortionary Taxation, May 2003

948 Steffen Huck and Kai A. Konrad, Strategic Trade Policy and Merger Profitability, May 2003

949 Frederick van der Ploeg, Beyond the Dogma of the Fixed Book Price Agreement, May 2003

950 Thomas Eichner and Rüdiger Pethig, A Microfoundation of Predator-Prey Dynamics, May 2003

951 Burkhard Heer and Bernd Süssmuth, Cold Progression and its Effects on Income Distribution, May 2003

$952 \mathrm{Yu}-\mathrm{Fu}$ Chen and Michael Funke, Labour Demand in Germany: An Assessment of NonWage Labour Costs, May 2003

953 Hans Gersbach and Hans Haller, Competitive Markets, Collective Decisions and Group Formation, May 2003

954 Armin Falk, Urs Fischbacher, and Simon Gächter, Living in Two Neighborhoods Social Interactions in the LAB, May 2003

955 Margarita Katsimi, Training, Job Security and Incentive Wages, May 2003

956 Clemens Fuest, Bernd Huber, and Jack Mintz, Capital Mobility and Tax Competition: A Survey, May 2003

957 Edward Castronova, The Price of 'Man' and 'Woman': A Hedonic Pricing Model of Avatar Attributes in a Synthetic World, June 2003 
958 Laura Bottazzi and Marco Da Rin, Financing Entrepreneurial Firms in Europe: Facts, Issues, and Research Agenda, June 2003

959 Bruno S. Frey and Matthias Benz, Being Independent is a Great Thing: Subjective Evaluations of Self-Employment and Hierarchy, June 2003

960 Aaron Tornell and Frank Westermann, Credit Market Imperfections in Middle Income Countries, June 2003

961 Hans-Werner Sinn and Wolfgang Ochel, Social Union, Convergence and Migration, June 2003

962 Michael P. Devereux, Measuring Taxes on Income from Capital, June 2003

963 Jakob de Haan, Jan-Egbert Sturm and Bjørn Volkerink, How to Measure the Tax Burden on Labour at the Macro-Level?, June 2003

964 Harry Grubert, The Tax Burden on Cross-Border Investment: Company Strategies and Country Responses, June 2003

965 Kirk A. Collins and James B. Davies, Measuring Effective Tax Rates on Human Capital: Methodology and an Application to Canada, June 2003

966 W. Steven Clark, Using Micro-Data to Assess Average Tax Rates, June 2003

967 Christopher Heady, The 'Taxing Wages' Approach to Measuring the Tax Burden on Labour, June 2003

968 Michael P. Devereux and Alexander Klemm, Measuring Taxes on Income from Capital: Evidence from the UK, June 2003

969 Bernhard Eckwert and Itzhak Zilcha, The Effect of Better Information on Income Inequality, June 2003

970 Hartmut Egger and Josef Falkinger, The Role of Public Infrastructure for Firm Location and International Outsourcing, June 2003

971 Dag Morten Dalen and Trond E. Olsen, Regulatory Competition and Multi-national Banking, June 2003

972 Matthias Wrede, Tax Deductibility of Commuting Expenses and Residential Land Use with more than one Center, June 2003

973 Alessandro Cigno and Annalisa Luporini, Scholarships or Student Loans? Subsidizing Higher Education in the Presence of Moral Hazard, June 2003

974 Chang Woon Nam, Andrea Gebauer and Rüdiger Parsche, Is the Completion of EU Single Market Hindered by VAT Evasion?, June 2003

975 Michael Braulke and Giacomo Corneo, Capital Taxation May Survive in Open Economies, July 2003 
976 Assar Lindbeck, An Essay on Welfare State Dynamics, July 2003

977 Henrik Jordahl and Luca Micheletto, Optimal Utilitarian Taxation and Horizontal Equity, July 2003

978 Martin D. D. Evans and Richard K. Lyons, Are Different-Currency Assets Imperfect Substitutes?, July 2003

979 Thorsten Bayindir-Upmann and Frank Stähler, Market Entry Regulation and International Competition, July 2003

980 Vivek Ghosal, Firm and Establishment Volatility: The Role of Sunk Costs, Profit Uncertainty and Technological Change, July 2003

981 Christopher A. Pissarides, Unemployment in Britain: A European Success Story, July 2003

982 Wolfgang Buchholz, Richard Cornes, and Wolfgang Peters, On the Frequency of Interior Cournot-Nash Equilibria in a Public Good Economy, July 2003

983 Syed M. Ahsan and Panagiotis Tsigaris, Choice of Tax Base Revisited: Cash Flow vs. Prepayment Approaches to Consumption Taxation, July 2003

984 Campbell Leith and Jim Malley, A Sectoral Analysis of Price-Setting Behavior in US Manufacturing Industries, July 2003

985 Hyun Park and Apostolis Philippopoulos, Choosing Club Membership under Tax Competition and Free Riding, July 2003

986 Federico Etro, Globalization and Political Geography, July 2003

987 Dan Ariely, Axel Ockenfels and Alvin E. Roth, An Experimental Analysis of Ending Rules in Internet Auctions, July 2003

988 Paola Conconi and Carlo Perroni, Self-Enforcing International Agreements and Domestic Policy Credibility, July 2003

989 Charles B. Blankart and Christian Kirchner, The Deadlock of the EU Budget: An Economic Analysis of Ways In and Ways Out, July 2003

990 M. Hasham Pesaran and Allan Timmermann, Small Sample Properties of Forecasts from Autoregressive Models under Structural Breaks, July 2003

991 Hyun Park, Apostolis Philippopoulos and Vangelis Vassilatos, On the Optimal Size of Public Sector under Rent-Seeking competition from State Coffers, July 2003 